\title{
Discussion on the Needed Abilities of Professional Teacher in University
}

\author{
Lei $\mathrm{Hu}$ \\ Chongqing Technology and Business University \\ Chongqing, China \\ 289592324@qq.com
}

\begin{abstract}
This paper investigates the basic meaning and major duties of teacher in university on basis of defining the meaning of university, professional course and professional teacher, then discuss the needed abilities of a professional teacher in university.
\end{abstract}

Keywords-University; Professional Course; Professional Teacher; Ability

\section{INTRODUCTION}

As the main executants of teaching, professional teacher plays important role in university, their ability is closely related to student's quality and ability. This paper discusses the professional teacher who teaches professional course in university, aiming at finding out the ability they needed.

\section{II.THE DEFINITION OF PROFESSIONAL TEACHER IN UNIVERSITY}

In order to fully understand the meaning of professional teacher, we must know its definition. This paper analyzes its intrinsic meaning from the definition of high school, professional course and teacher in university.

High school is the institution that set by related standards and approval procedures; it trains graduates of middle school as the main target, which includes the university, college, professional training institutions and so on.

Professional course and basic course are relative, professional course is referred to the professional knowledge and experience and is set based on the training objectives [1]. Its mission is to enable student to acquire the necessary and basic professional theory, professional knowledge and professional skills, grasp the foreword trend and technology, to develop the student's analytical ability to solve practical problems within the general professional scope.

Teacher is the man who educates others as job, maybe teaching in the school as a professional teacher, or can be a master who teaches the craft as a career [2].

We can see from the analysis above that professional teacher in university is someone who imparts knowledge to undergraduates of middle school and college students and dedicates to enable students to acquire the necessary professional skills, solve professional issues and get the ability to innovate, operate the corresponding engineering equipment skillfully, then satisfy the needs of the job market

\author{
Jiang Li \\ Dept. of Petroleum Supply Engineering \\ Logistical Engineering University \\ Chongqing, China. \\ lijiang830@163.com
}

and work requirement, the professional teacher's job is not to get direct economic benefits.

\section{THE NEEDED ABILITIES OF PROFESSIONAL TEACHER IN UNIVERSITY}

In order to achieve the demand of teaching professional course, professional teacher in university should have the following abilities.

\section{A. The ability to develop a firm political view}

The firm political view is what teacher in university must have, although it sounds with no real meaning. After the founding of new china, there have been some activities that against our country where students are the main force, there also have been defections of intellectuals, it threats not only the national economic but also the national security, which would damage the interest of the country and people greatly.

Professional teacher should strengthen their political education in their daily work, while focusing on professional knowledge learning at the same time. During the professional knowledge learning process, professional teacher should also arm themselves with the right political theory, and reject reactionary ideology to become an insulator of reactionary forces, and then transfers the firm political view in the process of teaching professional knowledge, finally let the student achieve the ability of develop a firm political view.

\section{$B$. The ability to shape a good image}

It was always said that "example is better than precept", professional teacher in university should have a good image. In order to give students a good example, they should have the ability to shape their own good image.

Image is the external appearance, posture and mental outlook of oneself [3].Good image includes two aspects: external image and internal image, which are embodied in the following aspects. First, the dress of professional teacher in university should be tidy and standard, Second, they should "stand like a pine, sit like a clock", maintain a good posture in the process of teaching, have good volitional quality as well, and then give subtle and inadvertent infection to students. Finally, they should have good teacher morality [4-6]. As is so-called "set good morality as an example", professional teacher must cultivate their own professional ethics, to be a model for others, strive to 
establish a good professional teacher image rather than do something contrary to the teacher behavior.

\section{The ability to master professional knowledge}

The professional knowledge amount that the teachers have is the key point which decides the education quality [7]. The biggest difference between professional course and basic course are that knowledge in basic course update relative slowly, but as time goes by, the new technology has been developed and professional course also goes like that, so it's not enough to teach professional course with the old teaching materials only.

"The metal itself must become hard if wanted to be turned into iron", professors should optimize their knowledge and make it keep up with the times to achieve their professional course's demand. What's more, they should stand in the leading edge of knowledge field, work in relative study, get their professional theory and skill rich, receive further education of their subject, strength the ability of teaching etc, so that they can show good performance while teaching in class.

It must not be ignored that professional course should put more energy on student's practical ability to make students master the practice skill, in other words, the professional teacher should also be armed with the sense of teaching more practical knowledge.

\section{The ability of self-reflection}

Many educators agree that the teacher who has the ability to reflect is a mature and highly qualified teacher [8].The ability of self-reflection refers to the ability of thinking and criticizing in the daily teaching practice, and professional teacher should have the ability to reflect them, it specifically includes the following aspects [9]:

The first one is the ability to reflect on their own ethics [10], moral construction is an important part of the construction of teacher in university, professional teachers' moral should be higher and more advanced than other occupations, so they have to learn to reflect.

The second one is to reflect on their own teaching ability [11], teaching philosophy is gradually formed and accumulated in the teaching process with relative stability, and it will be productive to the teaching practice if it is well reflected during the teaching process. Professional teacher in university should be diligent to reflect on their own teaching ideas, rather than stick to the old fashion, in order to let their own teaching philosophy meet the actual demand of the social changing.

The third one is the ability to reflect on their own teaching process and result, they should combine the teaching process and the teaching result through the characteristics of teaching achievement reflected by different teaching process, to reflect on the characteristic of teaching activities constantly and accumulate successful experience and then improve their teaching ability.

\section{SUMMARY}

This paper sums up the basic meaning of professional teacher in university with the definition of the university, professional course and teacher, on basis of that, shows out the four needed abilities what the professional teacher in university should have: the ability to develop a firm political view, the ability of shaping a good image, The ability to master professional knowledge and the ability of self-reflection, and then discusses their meaning. Results of this paper can provide theoretical guidance for the training of new teacher in university.

\section{REFERENCES}

[1] B. Wang. "Discuss on improving the practical teaching ability of professional teachers in Engineering Colleges", Chinese Adult Education, pp. 89-90, May, 2008.

[2] J.Z Qian, G.F Guan, B.S Cheng, "Research on the current situation of the practical teaching ability of young teachers in Higher Engineering Colleges and Universities", experiment technology and management, vol.31, pp. 183-186, 2014.

[3] W.B Zhang, D. Chen, "University Teachers' Ethics in the new area, the problems analysis of the causes and Countermeasures of Party construction and ideological education thinking of the", School party building and Ideological Education, pp. 69-70, Nov. 2006.

[4] Y.X Ji, "The key to improve the quality of teachers in Colleges and Universities", Heilongjiang Researches on Higher Education, pp. 85-86, Nov. 2006.

[5] D.X Wang, "Problems and treatment in the construction of teachers' morality in Colleges and Universities", Education Exploration, pp. 84-85, Oct. 2004.

[6] Z.Q Yu, "The significance and ways of strengthening the cultivation of professional ethics of teachers in Colleges and Universities", Police Education Forum, pp.138-141, Jul. 2005.

[7] X.L Hui, L. Ji, P. Xu, "Research on the training of young teachers' engineering practice ability in Higher Engineering Colleges", Education Science, pp. 65 -68, June 2010.

[8] Z. H. Zhang, C. Wang, "The renewal of teaching concept and reform trend of university teaching mode", Coal higher education, pp. 5-9, May 2011.

[9] H. Li, N. Deng, X.W Yang, "The teaching idea and its influence on Teaching", Teaching research, pp. 232-234, Mar. 2004.

[10] X. M. Yuan, "Challenges and Countermeasures of teaching ability Confronted by College Teachers", Higher Education and Economy, Higher Education and Economy, pp. 33, Jan. 2011. 
[11] Y. Q. Dong, "Coordinated development of common growth --2011 International Symposium of University Teachers' Development
Conference”, China University Teaching, pp. 92-93, May, 2012. 